\title{
Model Pembelajaran STAD Berorientasi THK Meningkatkan Kompetensi Pengetahuan IPA Siswa Kelas V Sekolah Dasar
}

\author{
Ni Putu Ayu Winaastari ${ }^{1}$, Kadek Yudiana ${ }^{2}$, Ni Nyoman Kusmariyatni ${ }^{3}$ \\ ${ }^{123}$ Prodi Pendidikan Guru Sekolah Dasar, Universitas Pendidikan Ganesha \\ Singaraja, Indonesia \\ e-mail: putu.ayu.winaastari@undiksha.ac.id, kadek.yudiana@undiksha.ac.id, \\ nyoman.kusmariyatni@undiksha.ac.id
}

\begin{abstract}
Abstrak
Masalah dalam penelitian ini adalah pembelajaran dengan model pembelajaran yang kurang inovatif yang mengakibatkan rendahnya kompetensi pengetahuan IPA siswa kelas V SD. Penelitian ini bertujuan untuk membuktikan apakah terdapat pengaruh yang signifikan model pembelajaran Student Teams Achivement Devision (STAD) berorientasi Tri Hita Kara (THK) terhadap kompetensi pengetahuan IPA siswa kelas V SD. Jenis penelitian yang dilakukan adalah penelitian yang bersifat quasi eksperiment menggunakan desain non-equivalent post-test only control group desaig pada populasi siswa sebanyak 210 orang dengan menggunakan sempel sebanyak 26 siswa pada kelompok eksperimen dan 22 orang siswa pada kelompok kontrol. Metode pengumpulan data yang dipergunakan adalah metode tes, bentuk tes yang dikembangkan adalah tes objektif dalam bentuk pilihan ganda. Hasil penelitian yang diperoleh dianalisis menggunakan analisis statistik deskriptif dengan menentukan mean, median, modus dan stadar deviasi serta menggunakan analisis statistik inferensial dengan melakukan uji homogenitas varian dan uji normalitas data serta uji hipotesis dengan menggunakan uji-t. Dari hasil perhitungan uji-t diperoleh $t_{\text {hitung }}=6,398$. Sedangkan $t_{\text {tabel }}$ pada taraf sighifikan $5 \%$ adalah 2,021 yang menunjukan bahwa $t_{\text {hitung }}>t_{\text {tabel }}(6,398>2,021)$, sehingga $H 0$ ditolak dan $\mathrm{H} 1$ diterima. Sehingga dinyatakan bahwa terdapat pengaruh yang signifikan model pembelajaran Student Teams Achievement Devision (STAD) berorientasi Tri Hita Karana (THK) terhadap kompetensi pengetahuan IPA di kelas V SD.
\end{abstract}

Kata kunci: STAD, THK, kompetensi pengetahuan IPA.

\begin{abstract}
Problem on this study learning is less innovative of learning model which low results of science knowledge competence of student on grade fifth in elementary school. The purpose of this study is to prove whether there is a significant influence of Student Teams Achievement Division (STAD) learning model oriented the Tri Hita Karana (THK) on the science competence of grade fifth elementary school. This type of research was a quasiexperimental study using a non-equivalent post-test only control group design in a population of 210 students by using a sample of 26 students in the experimental group and 22 students in the control group. Data collection method used is a test method, the form of test developed is an objective test in the form of multiple choice. The results obtained were analyzed using descriptive statistical analysis by determining the mean, median, mode and standard deviation and using inferential statistical analysis by performing variance homogeneity tests and data normality tests and hypothesis testing using t-tests. From the results of t-test calculations obtained $=6.398$. Whereas the significance level of $5 \%$ was 2.021 which showed that $(6.398>2.021)$, so $\mathrm{H} 0$ was rejected and $\mathrm{H} 1$ was accepted. So it is stated that there is a significant effect of the Student Teams Achievement Division learning model oriented Tri Hita Karana (THK) on the science knowledge competency in grade $\mathrm{V}$ elementary school.
\end{abstract}

Keywords: STAD, THK, science knowledge competency 


\section{Pendahuluan}

Proses pembelajaran di SD menekankan pada pengajaran ilmu pengetahuan dasar. Muatan pelajaran yang dibelajarkan mencangkup lima muatan pembelajaran wajib serta muatan lokal yang dibelajarkan dalam bentuk pembelajaran terpadu sesuai dengan ketentuan kurikulum 2013. Salah satu muatan pembelajaran yang di ajarkan adalah ilmu pengetahuan alam (IPA). (Purbosari 2016) menyatakan bahwa, IPA merupakan terjemahan kata-kata Inggris yaitu natural science. Natural artinya berhubungan dengan alam atau bersangkut paut dengan alam, sedangkan science artinya ilmu pengetahuan. Dengan demikian IImu Pengetahuan Alam (IPA) atau natural science dapat disebut sebagai ilmu tentang alam atau IImu yang mempelajari peristiwa-peristiwa yang terjadi di alam. Dengan demikian IPA merupakan muatan yang membahas berbagai materi dan teori tentang fenomena alam dan lingkungan hidup. Sedangkan Ariyanto (2016) menyatakan IPA adalah muatan pelajaran yang penting, yang mana pelajaran IPA dipelajari sejak pendidikan dasar, pelajaran IPA digunakan siswa untuk mempelajari hubungan manusia dengan alam dengan cara pengamatan dan pengumpulan konsep- konsep alam yang logis, sistematis dan bertujuan untuk sebuah penemuan. Menurut Putra (2017) tujuan muatan pelajaran IPA di SD/MI adalah (1) menumbuhkan keyakinan terhadap kebesaran Tuhan Yang Maha Esa berdasarkan keberadaan, keindahan dan keteraturan alam ciptaannya, (2) mengembangkan pengetahuan dalam bentuk rasa ingin tahu, sikap positif dan kesadaran tentang adanya hubungan yang saling mempengaruhi antara IPA, lingkungan, teknologi dan masyarakat, (3) mengembangkan keterampilan proses untuk menyelidiki alam sekitar, (4) memecahkan masalah dan membuat keputusan, serta meningkatkan pemahaman konsep-konsep IPA yang bermanfaat serta dapat diterapkan dalam kehidupan sehari-hari, (5) meningkatkan kesadaran untuk berperan serta dalam memelihara, dan menghargai lingkungan alam dan segala keteraturannya sebagai salah satu ciptaan Tuhan, (6) memperoleh bekal pengetahuan, konsep dan keterampilan IPA sebagai dasar untuk melanjutkan pendidikan ke SMP/MTs. Berdasarkan tujuan tersebut penguasaan kompetensi pengetahuan pada muatan IPA sangatlah penting Kosasih (2014:13) berpendapat bahwa, "pembelajaran berbasis kompetensi mengutamakan penciptaan dan peningkatan serangkaian kemampuan peserta didik". Pendapat lain menyatakan oleh bahwa, penilaian kompetensi pengetahuan atau kognitif adalah penilaian yang dilakukan guru untuk mengukur tingkat pencapaian atau penguasaan pemahaman, penerapan atau aplikasi, analisis, sintesis dan evaluasi (Khunadar 2014). Dengan demikian kompetensi pengetahuan IPA merupakan merupakan penilaian yang dilakukan oleh guru untuk mengukur tingkat pemahaman dan penguasaan anak dalam materi pembelajaran IPA. Hal tersebut menunjukan pentingnya bagi siswa seluruh siswa untuk mampu mencapai hasil yang optimal dalam kompetensi pengetahuan IPA agar tujuan pembelajaran dapat tercapai. Untuk mengetahui bagaimana pencapaian hasi belajar siswa pada kompetensi pengetahuan IPA maka perlu dilakukan pengamatan secara langsung dilapangan.

Pengamatan dilapangan dilakukan melalui kegiatan observasi dan wawancara yang dilaksanakan di SD Gugus V Kecamatan Sukasada, melalui kegiatan observasi kelas, wawancara langsung dengan narasumber dan pengumpulan dokumentasi ditemukan beberapa permasalahan dintaranya guru kurang mampu menerapkan model dan metode pembelajaran yang inovatif sehingga siswa masih kesulitan dalam memahami materi ajar, konsentrasi belajar siswa kurang baik yang ditunjukan dari tingkah laku siswa yang kurang fokus pada proses pembelajaran, kurangnya pemberian kuis untuk mengukur kemampuan siswa sehingga siswa kurang memiliki minat dalam berkompetisi untuk menunjukan kemampuan dalam ranah kognitif, kesulitan siswa dalam memahami materi dan soal yang disajikan, muatan pelajaran yang telah tergabung dalam pembelajaran terpadu menyebabkan siswa tidak begitu mendalami tiap-tiap materi secara utuh, siswa kurang paham terhadap materi yang diajarkan sehingga siswa tidak begitu aktif secara individu maupun dalam kegiatan diskusi. Permasalahan diatas merupakan permasalahan yang kerap kali di temukan pada proses pembelajaran di SD pada umumnya. Dari permasalahan yang ada penelitian ini difokuskan pada satu permasalahan karena keterbatasan waktu, biaya, kemapuan dan fasilitas yang dimiliki oleh peneliti, permasalah yang diteliti berfokus pada penggunaan model pembelajaran yang kurang tepat serta kurang inovatif, permasalahan tersebut memiliki 
dampak yang cukup besar terhadap proses pembelajaran dikelas. Untuk dapat menumbuhkan minat belajar dan berkompetisi bagi siswa dibutuhkan model pembelajaran yang mampu menumbuhkan motivasi serta semangat berkompetisi antar siswa dengan tetap menjaga pola interaksi atau hubungan yang baikantara siswa dengan lingkungan belajarnya, baik lingkungan sosial maupun yang bersifat sepiritual, sehingga selain mempu memahami materi ajar dengan baik siswa juga mampu mengimplementasikan ilmu yang diperolehnya dalam kehidupan sehari-hari. Salah satu bentuk model pembelajaran yang diduga sesuai dengan permasalah tersebut adalah Model Pembelajaran Student Teams Achivement Division (STAD) Berorientasi Tri Hita Karana (THK).

Model Pembelajaran Student Teams Achievement Devision merupakan salah satu model pembelajaran kooperatif, model ini dikembangkan oleh Robet Slavin beserta rekanrekannya di Johns Hopkis University. Slavin (dalam Esminarto 2016) menyatakan "In cooperative learning methods, students work together in four member teams to master material initially presented by the teacher" ini pembelajaran kooperatif adalah suatu model pembelajaran dimana sistem belajar dan bekerja kelompok-kelompok kecil berjumlah 4-6 orang secara kolaboratif sehingga dapat merangsang peserta didik lebih bergairah dalam belajar. Sehingga dapat dikatakan bahwa model pembelajaran Student Teams Achievement Devision merupakan model kooperatif dengan cara belajar dalam bentuk kelompok-kelompok kecil yang saling bekerjasama dan diarahkan oleh guru untuk mencapai tujuan pembelajaran yang diharapkan. Menurut Rahayu dan Nuryata (2013:169) model pembelajaran "Student Teams Achievement Devision merupakan pendekatan cooperative learning yang paling mudah dipahami". Guru yang menggunakan model pembelajaran Student Teams Achievement Devision menyajikan informasi akademis baru, kepada peserta didik secara reguler setiap minggu baik melalui presentasi verbal maupun teks. Pembelajaran kooperatif tipe Student Teams Achievement Devision (STAD) merupakan suatu model pembelajaran yang diterapkan dengan membentuk kelompok atau tim belajar yang beranggotakan empat atau lima orang dan bersifat heterogen atau campuran dari kemampuan akademik yang berbeda, sehingga dalam penerapannya model pembelajaran Student Teams Achievement memberikan informasi akademik baru kepada peserta didik setiap minggu menggunakan presentasi verbal atau teks dan disertai dengan pemberian kuis secara individu ataupun kelompok. Sedangkan Rumas (dalam Sudana 2017) menyatakan bahwa model pembelajaran kooperatif STAD merupakan strategi alternative untuk mencapai tujuan pembelajaran IPA antara lain meningkatkan kemampuan siswa untuk antara lain bekerjasama dengan siswa lain, dan pada saat yang bersamaan dapat meningatkan prestasi akademik siswa. Hal ini menjadikan model pembelajaran (Putra., dkk 2018) Model Pembelajaran Student Teams Achievement Devision (STAD) memeliki beberapa kelebihan menurut Budairi (dalam Solihah 2016) model pembelajaran Student Teams Achievement Devision (STAD) memiliki kelebihan di antaranya: siswa bekerja sama dalam mencapai tujuan dengan menjunjung tinggi norma-norma kelompok, siswa akan memiliki rasa kekeluargaan dan sikap social yang tinggi sehinga siswa akan menjadi aktif saling membantu, saling memotivasi dan memberikan semangat untuk keberhasilan bersama, seluruh anggota kelompok akan aktif berperan sebagai tutor sebaya untuk lebih meningkatkan keberhasilan kelompok. Kelebihan dari model pembelajaran kooperatif tipe STAD yang dikemukakan oleh Shoimin ( dalam Rima Yusi Christian dan Mawardi 2018) yaitu peserta didik bekerja sama untuk mencapai tujuan dengan menjunjung tinggi norma-norma kelompok, peserta didik aktif membantu dan memotivasi semangat anggota kelompoknya untuk berhasil bersama, dapat aktif berperan sebagai tutor dan lebih meningkatkan keberhasilan kelompok, terjalin interaksi antar kelompok seiring dengan peningkatan kemampuan mereka dalam berpendapat, serta dapat meningkatkan kecakapan secara individu dan kelompok

Yasir (2015) menyatakan bahwa, langkah-langkah model pembelajaran Kooperatif Tipe Student Teams Achievement Division terdiri atas enam langkah yaitu: 1) menyampaikan tujuan pembelajaran yang ingin dicapai pada pembelajaran tersebut dan memberikan motivasi pada belajar pada siswa, 2) menyajikan informasi kepada siswa dengan jalan 
mendemonstrasikan atau lewat bahan bacaan, 3) mengorganisasikan atau membentuk siswa dalam kelompok-kelompok belajar, 4) menjelaskan kepada siswa bagaimana caranya membentuk kelompok belajar dan membentuk setiap kelompok agar melakukan transisi secara efesien, 5) membimbing kelompok bekerja dan belajar, 6) membimbing kelompokkelompok belajar pada saat mereka mengerjakan tugas mereka. 7) Evaluasi, mengevaluasi kompetensi pengetahuan IPA tentang materi yang telah diajarkan atau masing-masing kelompok mempresentasikan hasil kerjanya, 8) Memberikan penghargaan, Melalui berbagai cara yang sesuai dalam konteks pembelajaran untuk menghargai baik upaya maupun proses dan hasil belajar individu dan kelompoknya.

Tri Hita Karana merupakan salah satu, bentuk kearifan lokal dari kebudayaan masyrakat Bali yang berkembang sebagai sebuah filsafat secara universal, Tri Hita Karana merupakan sebuah pola interaksi yang dibangun dalam bentuk hubungan yang seimbang antar berbagai komponen konsep Tri Hita Karana mengarahkan pada bentuk pola pembelajaran di kelas yang berorientasi pada hubungan yang baik dengan sesama, dengan lingkungan dan Tuhan, yang akan menumbuhkan karakter siswa dalam proses pembelajaran. (Wardani., dkk 2015:100) menyatakan bahwa, "Tri Hita Karana merupakan tiga penyebab kesejahteraan dan keharmonisan dalam menjalin hubungan atau interaksi dengan sesama, lingkungan, dan Tuhan". Hardyanti (2017)juga memiliki pendapat yang hampir serupa yang menyatakan bahwa hakikat mendasar Tri Hita Karana merupakan tiga penyebab kesejahteraan, yang bersumber pada keharmonisan hubungan antara Manusia dengan Tuhannya, Manusia dengan alam lingkungannya, dan Manusia dengan sesamanya. Dengan menerapkan falsafah tersebut diharapkan dapat menggantikan pandangan hidup modern yang lebih mengedepankan individualisme dan materialisme. Paramandhita (2017) menyatakan bahwa, Tri Hita Karana merupakan tiga hubungan manusia dalam kehidupan di dunia ini. Ketiga hubungan itu meliputi hubungan antara manusia dengan Tuhan, hubungan antara manusia ke sesama manusia dan hubungan antara manusia dengan lingkungan atau alam sekeliling. Setiap hubungan memiliki pedoman hidup menghargai sesama dengan prinsip pelaksanaannya yang harus seimbang, selaras antara satu dan lainnya. Ketiga hubungan tersebut memiliki ketekaitan yang akan menjadi landasan untuk menjalani kehidupan sehari-hari secara sosial maupun secara sepiritual. Menurut (Wibisana., dkk 2019), "bagian-bagian dari Tri Hita Karana adalah Parahyangan, bentuk hubungan antara manusia dengan Tuhan, Pawongan, bentuk hubungan antara manusia dengan manusia, Palemahan, bentuk hubungan antara manusia dengan lingkungannya. Dengan menerapkan pembelajaran yang berorientasi Tri Hita Karana maka dalam proses pemebelajaran akan terwujud kehidupan harmonis yang meliputi pembangunan manusia seutuhnya terhadap Tuhan Yang Maha Esa, cinta kepada kelestarian lingkungan serta rukun dan damai dengan sesamanya. Tri Hita Karana telah diaplikasikan di seluruh dunia, tentu saja tidak menggunakan istilah bakunya, tetapi hal yang terpenting bahwa manusia di dunia menyadari bahwa kebenaran konsep itu telah terbukti. Dengan menerapkan pembelajaran yang berorientasi Tri Hita Karana maka dalam proses pemebelajaran akan terwujud kehidupan harmonis yang meliputi pembangunan manusia seutuhnya terhadap Tuhan Yang Maha Esa, cinta kepada kelestarian lingkungan serta rukun dan damai dengan sesamanya. Tri Hita Karana telah diaplikasikan di seluruh dunia, tentu saja tidak menggunakan istilah bakunya, tetapi hal yang terpenting bahwa manusia di dunia menyadari bahwa kebenaran konsep itu telah terbukti.

Menurut Emilia dan Wasitohadi (2019) model pembelajaran Student Teams Achievement Devision yang merupakan model yang efektif dalam mengembangkan sikap sosial. Hal ini menujukan kesesuaian antara Model Pembelajaran Student Teams Achievement Devision dengan konsep Tri Hita Karana untuk meningkatkan kompetensi pengetahuan IPA. Implementasi model pembelajaran Student Teams Achievement Devision berorientasi Tri Hita Karana dalam bentuk proses pembelajaran yang diterapkan, dalam sintak-sintak pembelajaran yang akan dimuat dalam kegiatan inti pembelajaran. 1) Penyampaian materi dan pemberian motivasi. Mengawali kegiatan pembelajaran dengan doa bersama siswa dalam bentuk rasa syukur kehadapan Tuhan Yang Maha Esa dan menjelaskan tujuan pembelajaran, mengajukan fenomena atau demonstrasi atau cerita untuk memotivasi 
siswa dan menjelaskan materi yang akan dibelajarkan melalui berbagai contoh dan fenomena yang terdapat dilingkungan sekitar dan mengajak siswa untuk lebih memperhatikan hal-hal yang terdapat dilingkungan sekitarnya, 2) Pembentukan kelompok. mengarahkan siswa untuk membentuk kelompok heterogen yang beranggotakan 4-5 orang dan memotivasi siswa untuk belajar dan menyelesaikan masalah Bersama berkelompoknya. Tahap ini menunjukan penerapan konsep pawongan (hubungan manusia dengan manusia, 3) Diskusi kelompok. mengerjakan tugas dengan cara diskusi Bersama anggota kelompok, siswa belajar untuk bertoleransi satu sama lain, membangun kepercayaan dan membantu membimbing teman sejawatnya. Tahap ini menunjukan penerapan konsep Pawongan (hubungan manusia dengan manusi), 4) Publikasi. Mempresentasikan hasil diskusi di depan kelas. Pada tahap ini siswa mencoba menyampaikan hasil yang diperoleh dari tahap diskusi, tahap ini mendorong siswa untuk belajar berkomunikasi dan berinteraksi dengan baik. Tahap ini merupakan penerapankonsep Pawongan (hubungan manusia dengan manusia), 5) Pemberian Kuis dan penghargaan. Menjawab pertanyaan dari guru, menerima reward dan penghargaan apabila siswa menjawab pertanyaan dengan benar, tahap ini menunjukan penerapan konsep Pawongan (hubungan manusia dengan manusia). 6) Evaluasi. Memberikan lembar evaluasi kepada siswa dan meminta siswa untuk bersikap jujur, percaya diri dan mandiri dalam nyelesaikan soal, siswa juga diminta untuk menemukan jawaban berdasarkan pada pengetahuan dan pengalaman yang diperoleh dari lingkungan sekitarnya. pada tahap ini bersikap jujur ditunjukan untuk mengimplementasikan sikap spiritual yang tinggi. Tahap ini sesuai dengan konsep Parahyangan (hubungan manusia dengan Tuhan) bersikap percaya diri dan mandiri Akan membangun rasa sportifitas dan saling percaya serta adil bagi siswa. Tahap ini menunjukan penerapan konsep Pawongan (hubungan yang baik denga sesama manusia) memperoleh pengetahuan berdasakan pengalaman yang diperoleh di lingkungan sekitar menunjukan keperdulian siswa pada berbagai hal di lingkungan sekitanya. Tahap ini merupakan penerapan konsep Palemahan (hubungan manusia dengan alam sekitar). Melalui pembelajaran dengan menggunakan model pembelajaran Student Teams Achivement Division Berorientasi Tri Hita Karana, siswa diharapkan lebih memahami konsep IPA dengan menggunakan model kooperatif yang efektif disertai dengan contoh relevan yang ditemukan melalui pengamalan dalam menerapkan pola interaksi sesuai konsep Tri Hita Karana. Berdasarkan berbagai ulasan materi serta teori yang telah disampaikan maka tujuan dari pelaksanaan penelitian ini adalah untuk menentukan apakah terdapat pengaruh yang signifik model pembelajaran Student Teams Achievement Devision (STAD) berorientasi Tri Hita Karana (THK) terhadap kompetensi pengetahuan IPA di kelas V SD Gugus V Kecamatan Sukasada Kabupaten Buleleng Tahun pelajaran 2019/2020.

\section{Metode}

Penelitian ini dilaksan di SD Gugus I Kecamatan V Sukasada Kabupaten Buleleng. Pelaksanan penelitian pada Smester II tahun pelajaran 2019/2020, tepatnya pada bulan Januari 2020 dengan menggunakan unit experimen berupa kelas dan tidak semua variabel dalam kondisi eksperimen dapat diatur dan dikontrol dengan ketat. Penelitian yang dipergunakan adalah eksperimen semu (quasi eksperiment). Dalam eksperimen semu, individu subjek sudah terdapat dalam kelompok yang dibandingkan, sebelum diadakannya penelitian, penempatan subjek ke dalam kelompok yang dibandingkan tidak dilakukan secara acak. Penelitian ini menguji pengaruh antara model pembelajaran Student teams achievement division (STAD) berorientasi Tri Hita Karana (THK)tehadap kompetensi pengetahuan IPA siswa.

Populasi dalam penelitian ini adalah kelas V SD di Gugus V Kecamatan Sukasada Kabupaten Buleleng, untuk mengetahui tingkat kesetaraan dari masing-masing kelas di tiap sekolah dasar yang dipergunakan sebagai sampel, maka dilakukan uji kesetaraan untuk mengetahui apakah kedua kelas tersebut setara atau tidak. Uji kesetaraan dilakukan dengan menganalisis hasil ulangan tengah semester pada kompetensi pengetahuan IPA disemester I dan akan dilakukan uji kesetraan dengan menggunakan analisis varians satu jalur (Anava A).

\footnotetext{
Received 19 April 2020, Accepted 19 Juni 2020; Available online 5 Juli 2020
} 
Kriteria pengujiannya, jika $F_{\text {hitung }}>F_{\text {tabel, }}$ maka $\mathrm{H}_{0}$ ditolak dan $\mathrm{H}_{1}$ diterima sehingga kelompok tersebut diinterpretasikan tidak setara. Jika $\mathrm{F}_{\text {hitung, }}<\mathrm{F}_{\text {tabel, }}$ maka $\mathrm{H}_{0}$ diterima dan $\mathrm{H}_{1}$ ditolak sehingga kelompok tersebut setara. Pengujian dilakukan pada taraf signifikan $5 \%$. Dari hasil analisis menggunakan uji Anava A satu jalur dengan bantuan Microsort Exel 2019 for Windows pada taraf signifikasi $5 \%$ didapatkan $F_{\text {hitung }}$ sebesar 0,92. Sedangkan, nilai $F_{\text {tabel }}$ pada taraf signifikan $5 \%$ dengan $\mathrm{db}_{\mathrm{A}}=8$ dan $\mathrm{db}_{\mathrm{dal}}=201$ adalah 1,98. Hasil perhitungan menunjukan $\mathrm{H}_{0}$ diterima sedangkan $\mathrm{H}_{1}$ ditolak karena $\mathrm{F}_{\text {hitung }}<\mathrm{F}_{\text {tabel. }}$ Jadi dapat disimpulkan bahwa tidak ada perbedaan hasil ulangan tengah semester pada muatan pelajaran IPA siswa kelas V SD Gugus V Kecamatan Sukasada Kabupaten Buleleng. Ini membuktikan bahwa kemampuan siswa kelas IV SD Gugus V Kecamatan Sukasada Kabupaten Buleleng dinyatakan setara.

Data yang dikumpulkan dalam penelitian ini adalah kompetensi pengetahuan IPA kelas V di SD Negeri 1 Panji dan SD Negeri 2 Panji. Metode pengumpulan data yang dipergunakan dalam penelitian ini adalah metode tes. Tes adalah suatu alat atau prosedur yang terencana dan sistematis untuk mengukur suatu prilaku tertentu serta menggambarkannya dengan bantuan angka-angka atau kategori tertentu (Koyan, 2011: 15). Metode yang digunakan adalah tes. Bentuk tes kompetensi pengetahuan yang dikembangkan adalah tes objektif dalam bentuk pilihan ganda. Metode tes dilakukan dengan membandingkan sejumlah tes untuk mengukur kompetensi pengetahuan IPA. Setiap butir soal akan diberikan skor 1 apabila siswa menjawab dengan benar serta skor 0 untuk siswa yang menjawab salah, skor setiap jawaban kemudian dijumlahkan dan jumlah skor tersebut merupakan skor variabel kompetensi pengetahuan IPA. Penyusunan tes instrument tes kompetensi pengetahuan IPA. penyusunan instrument tes berpedoman pada kisi-kisi tes pada tema 6 "Panas dan perpindahannya" yang telah di susun berdasarkan kompetensi dasar dan Indikator. Kompetensi dasar yang dipergunakan adalah 3.6 menerapkan konsep perpindahan kalor dalam kehidupan sehari-hari. Serta menggunakan 8 indikator dari pembelajaran 1 sampai dengan pembelajaran 9. Dengan jumlah soal pada tahap awal sebanyak 40 butir soal. Untuk menentukan kelayakan dari instrument tersebut maka dilakukan uji validitas tes (isi dan butir), reliabilitas tes, taraf kesukarann tes, dan daya beda soal serta uji pakar sebelum tes dipergunakan dalam kegiatan penelitian. Dari proses uji tersebut diperoleh sebanyak 30 soal dinyatakan layak untuk di pergunakan dalam kegiatan pemberian post-test.

Penelitian menggunakan teknik analisis deskriptif dan statistik inferensial. Analisis statistik deskriptif berfungsi untuk mengelompokkan data, menyelesaikan, memaparkan, serta menyajikan hasil olahan. Statistik deskriptif yang digunakan dalam penelitian ini yaitu nilai ratarata (mean), median (nilai tengah), modus dan standar deviasi (SD). Sedangkan statistik inferensial berfungsi untuk menggeneralisasi hasil penelitian yang dilakukan pada sampel bagi populasi. Statistik inferensial yang digunakan dalam penelitian ini adalah analisis parametrik yang meliputi uji normalitas sebaran data dan uji homogenitas varians sedangkan analisis data yang digunakan untuk menganalisis hasil penelitian yaitu metode analisis uji-t atau t-test. Apabila uji-t meninjukkan bahwa $\mathrm{Ho}$ ditolak dan $\mathrm{H}_{1}$ diterima, maka dapat disimpulkan bahwa terdapat pengaruh yang signifik model pembelajaran Student Teams Achievement Devision (STAD) berorientasi Tri Hita Karana (THK) terhadap kompetensi pengetahuan IPA di kelas V SD Gugus V Kecamatan Sukasada Kabupaten Buleleng Tahun pelajaran 2019/2020.

\section{Hasil dan Pembahasan}

Data yang telah diperoleh dalam penelitian ini disusun dan dipergunakan sesuai dengan kebutuhan analisis penelitian yang dilakukan. Pelaksanaan penelitian dilakukan sebanyak 7 kali pertemuan sesuai dengan jadwal pembelajaran pada masing-masing kelompok atau sekolah. Data diperoleh melalui post-test terhadap kelompok eksperimen dan kontrol, sebanyak siswa 26 siswa pada kelompok eksperimen dan 22 pada kelompok kontrol. Setelah itu data yang telah dikumpulkan di analisis dan ditentungan rentangan data (range) dan panjang kelas interval pada masing-masing kelompok sebelum menyajikan ke dalam tabel distribusi frekuensi. rentangan data yang diperoleh pada kelompok eksperimen adalah 14 dengan Panjang kelas batas kelas interval 15 sedangkan pada kelompok kontrol rentangan 
data yang diperoleh adalah 15 dengan batas kelas interval 16. Rangkuman hasil deskripsi data post-test kompetensi pengetahuan IPA pada penelitian dapat dilihat pada Tabel 01.

Tabel 01. Rangkuman Perhitungan Skor Hasil Post-test Kompetensi Pengetahuan IPA

Stastik Deskriptif

Hasil Belajar IPA

\begin{tabular}{lcc}
\cline { 2 - 3 } \multicolumn{1}{c}{ Stastik Deskriptif } & Kelompok Eksperimen & Kelompok Kontrol \\
\cline { 2 - 3 } $\mathrm{N}$ & 26 & 22 \\
Mean & 22,23 & 15,32 \\
Median & 25 & 15 \\
Modus & 23 & 15 \\
Standar Deviasi & 11,44 & 17,40 \\
Varians & 3,38 & 4,17 \\
Skor Tertinggi & 28 & 22 \\
Skor Terendah & 15 & 8 \\
Rentangan & 14 & 15 \\
\hline
\end{tabular}

Sebelum melanjtkan ketahap uji hipotesis terlebih dahulu dilakukan uji prasyarat. Uji prasyarat yang harus dipenuhi adalah uji normalitas dan uji homogenitas. Uji normalitas sebaran data dilakukan untuk mengetahui apakah data yang diperoleh berdistribusi normal atau tidak. Uji normalitas data dilakukan terhadap hasil post-test kelompok eksperimen dan kelompok kontrol. Uji homogenitas untuk mengetahui bahwa kedua kelompok mempunyai varians yang homogen.

Tabel 02.

Hasil Analisis Uji Prasyarat (Uji Homogenitas varians dan Uji Normalitas Sebaran Data)

Berdasarkan dari hasil perhitungan uji normalitas sebaran data dengan menggunakan

\begin{tabular}{lllllllll}
\hline No & Kelompok & $\mathrm{x}_{\text {Hitung }}^{2}$ & $\mathrm{x}_{\text {tabel }}^{2}$ & Status & Varians & $\mathbf{f}_{\text {hitung }}$ & $\mathbf{f}_{\text {tabel }}$ & Status \\
\hline 1 & $\begin{array}{l}\text { Kelompok } \\
\text { Eksperimen }\end{array}$ & 8,65 & 19,675 & Normal & 11,44 & 1,52 & 4,05 & Homogen \\
\hline 2 & $\begin{array}{l}\text { Kelompok } \\
\text { Kontrol }\end{array}$ & 15,65 & 16,919 & Normal & 17,40 & & & \\
\hline
\end{tabular}

bantuan Microsoft Excel 2019 for Wondows, uji normalitas sedaran data dengan rumus ChiSquare $\left(\mathrm{x}^{2}\right)$ menunjukan hasil $?_{\text {hitung }}^{2}$ pada kelompok eksperimen sebesar 8,65 . Sedangkan

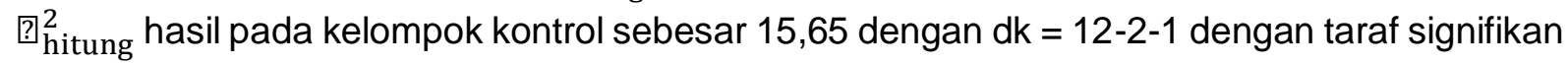
$5 \%$ sehingga didapat harga $?_{\text {tabel }}^{2}$ sebesar 19,675 pada kelompok eksperimen dan 16,919 pada kelompok kontrol. Berdasarkan hasil perhitung tersebut maka diperoleh hasil post-test pada kelompok eksperimen dan kelompok kontrol lebih kecil dari pada ? $?_{\text {tabel }}^{2}$ ( $?_{\text {hitung }}^{2}<$ ? $_{\text {tabel }}^{2}$ )dengan demikian data hasil post-test pada kompetensi pengetahuan IPA kelompok eksperimen dan kelompok kontrol berdistribusi normal selanjutnya untuk mengetahui homogenitas kedua kelompok maka dilakukan uji homogenitas data,

Dengan menggunakan uji $\mathrm{f}$, dari hasil perhitungan diketahui $\mathrm{F}_{\text {hitung }}$ dari hasil post-test pada kompetensi pengetahuan IPA kelompok eksperimen dan kelompok kontrol adalah 1,52. Sedangkan $\mathrm{F}_{\text {tabel }}$ dengan $\mathrm{db}_{\text {pembilang }}=1, \mathrm{db}_{\text {penyebut }}=46$ dengan taraf signifikan $5 \%$ adalah 4,05. Hasil ini menunjukan bahwa data post-test pada kompetensi pengetahuan IPA kelompok eksperimen dan kelompok kontrol bersifat homogen.

Tabel 05. Hasil Analisis Uji-t 


\begin{tabular}{|c|c|c|c|c|c|c|}
\hline Kelompok & $\mathbf{n}$ & $\mathbf{d b}$ & Mean $(\bar{x})$ & $\mathbf{s}^{2}$ & $t_{\text {hitung }}$ & $t_{\text {tabel }}$ \\
\hline Eksperimen & 26 & 46 & 22,23 & 11,40 & 6.398 & 2021 \\
\hline Kontrol & 22 & 46 & 15,32 & 17,44 & b,398 & 2,021 \\
\hline
\end{tabular}

Berdasarkan hasil analisis uji-t untuk kompetensi pengetahuan IPA dengan rumus polled varians, hasil thitung $=6,398$. Sedangkan tabel pada taraf sighifikan $5 \%$ dengan $\mathrm{db} 46$ $(26+22-2)$ adalah 2,021. Hal tersebut menunjukan bahwa thitung $>t_{\text {tabel }}(6,398>2,021)$, sehingga HO ditolak dan H1 diterima. Dengan demikian, dinyatakan bahwa terdapat pengaruh yang signifik model pembelajaran Student Teams Achievement Devision (STAD) berorientasi Tri Hita Karana (THK) terhadap kompetensi pengetahuan IPA di kelas V SD Gugus V Kecamatan Sukasada Kabupaten Buleleng Tahun pelajaran 2019/2020.

\section{Simpulan}

Berdasakan hasil analisis data dari penelitian dan pembahasan yang telah dilakukan menunjukan bahwa nilai rata-rata pada kelompok eksperimen yaitu 22,23 dan rata-rata pada kelompok kontrol yaitu 15,32. Dengan pengujian hipotesis menggunakan uji-t maka didaptakan hasil thitung $=6,398$. Sedangkan $t_{\text {tabel }}$ pada taraf sighifikan $5 \%$ dengan db $46(26+22-$ 2) adalah 2,021. Hal tersebut menunjukan bahwa $t_{\text {hitung }}>t_{\text {tabel }}(6,398>2,021)$, sehingga $\mathrm{H} 0$ ditolak dan $\mathrm{H} 1$ diterima. Dengan demikian, dinyatakan bahwa terdapat pengaruh yang signifik model pembelajaran Student Teams Achievement Devision (STAD) berorientasi Tri Hita Karana (THK) terhadap kompetensi pengetahuan IPA di kelas V SD Gugus V Kecamatan Sukasada Kabupaten Buleleng Tahun pelajaran 2019/2020. Hasil penelitian ini sejalan dengan penelitian yang dilakukan oleh (Utami., dkk 2019) Pembelajaran dengan menggunakan model pembelajaran kooperatif tipe Student Team Achievement Division dapat meningkatkan aktivitas dan interaksi diantara peserta didik untuk saling memotivasi dan membantu dalam menguasai materi pelajaran, peserta didik berperan sebagai tutor sebaya untuk lebih meningkatkan keberhasilan kelompok, dapat meningkatkan kecakapan individu dan kelompok, serta dengan diterapkannya model pembelajaran kooperatif tipe Student Team Achievement Division dapat meningkatkan hasil belajar peserta didik terutama dalam pemahaman materi. model pembelajaran Student Teams Achievement Devision berorientasi Tri Hita Karana disarankan agar siswa untuk lebih berperan aktif dalam melaksanakan kegiatan pembelajaran melalui diskusi antar kelompok kesempatan siswa untuk lebih aktif, kreatif, komunikatif dan inovatif akan semakin tinggi. Kesempatan untuk melatih kempuan bekerja sama juga akan menambah kemampuan bersosialisasi siswa, selain itu siswa juga diharapkan menguasai materi secara individu dan memiliki motivasi yang kuat dalam meningkatkan kemampuan setiap harinya. Guru sebagai pendidik disarankan untuk mengarahkan siswa dan memantau setiap perkembangan siswa dalam kelompok serta menyajikan kegiatan kelompok yang menyenangkan serta membangun kompetisi antar siswa. Bagi sekolah di harapkan agar mengadakan pelatihan dan mewadahi kreatifitas guru dan siswa dalam berbagai bidang. Hasil penelitian ini dapat dipergunkan sebagai referensi dan rujukan khususnya yang meneliti tentang model pembelajaran pembelajaran Student Teams Achievement Devision dan ajaran tri hita karana. Sehingga dapat dijadikan bahan pertimbangan dan penyemurnaan bagi penelitian di tahan selanjutnya.

\section{Daftar Pustaka}

Agung, A.A G. 2014. Buku Ajar Metodologi Penelitian Pendidikan. Yogyakarta: Aditya Media Publishing.

Anjani. 2017. "Model Pembelajaran Student Teams Achievement Divisions Berbasis Tri Hita Karana Berpengaruh Terhadap Kompetensi Pengetahuan Ipa. Mimbar Pgsd Undiksha, 5(2), 1-10

Arismunandar \& Hengki Wijaya. 2018. Pengembangan Model Pembelajaran Kooperatif Tipe STAD Berbasis Media Sosial. Jurnal Jaffray16(2): 175-96.

Ariyanto, Metta. 2016. Peningkatan Hasil Belajar Ipa Materi Kenampakan Rupa Bumi Menggunakan Model Scramble. Jurnal ISSN 3(2): 134-40. 
Christian, Rima Yusi., dkk 2018. "Perbedaan Hasil Belajar Matematika Menggunakan Model Student Team Achievment Divisions ( Stad) Dan Teams Game Tournament ( Tgt ) Siswa Kelas 4 Sd. 2(1), 75-84.

Dantes, N. 2017. Desain Eksperimen dan Analisis Data. Depok: Rajawali Pers.

Emilia., dkk. 2019. Perbedaan Pengaruh Model Kooperatif Tipe Tgt Dan Stad Dengan Multimedia Interaktif Ceria Terhadap Sikap Sosial Dan Hasil Belajar Kognitif Pada Pembelajaran Tematik Kelas $5 \mathrm{Sd}$. Jurnal basicedu 3(2): 524-32.

Esminarto. 2016. Implementasi Model Stad Dalam Meningkatkan Hasil Belajar Siwa .Jurnal Riset Dan Konseptual,1(1), 16-23.

Evri, Wardani., Anik Yuestini, \& I Made Sudiartana. 2016: 99-112.

Fadhilaturrahmi. 2019. Pengaruh Pembelajaran Kooperatif Tipe Gi Terhadap Peningkatan Kemampuan Koneksi Matematik Siswa Sekolah Dasar: Jurnal IImu Pendidikan 1(1): 4355.

Hardyanti., dkk. 2017. Penilaian Sistem Pengendalian Intern Dengan Konsep Tri Hita Karana Pada Perkumpulan Petani Pengguna Air ( P3a ) Subak Tibu Beleng Di Desa Penyaringan Kecamatan: Jurusan Akuntansi Program S1 7(1).

Khunandar. 2014. Penilaian Autentik.Jakarta: PT RajaGrafindo Persada.

Kosasi.2013. Strategi Bealajar dan Pembelajaran Implementasi Kurikulum 2013. Bandung: Yrama Widya

Koyan, I. W. 2012. Statistik Pendidikan Teknik Analisis Data Kuantitatif. Singaraja: Universitas Pendidikan Ganesha Press

Lestari. 2017. Pengaruh Model Pembelajaran Kooperatif Tipe Student Teams Achievement Divisions Berbantuan Mind Mapping Terhadap Kompetensi Pengetahuan Ipa Siswa Kelas V Sd Gugus Kompyang Sujana Denpasar Utara Tahun Ajaran 2016/2017: eJournal PGSD Universitas Pendidikan Ganesha Mimbar Pgsd Undiksha 5(2).

Noviana, Eddy. \& Muhammad Nailul Huda. 2018. "Penerapan Model Pembelajaran Kooperatif Tipe Stad Untuk Meningkatkan Hasil Belajar Pkn Siswa Kelas Iv Sd Negeri 79 Pekanbaru." Primary: Jurnal Pendidikan Guru Sekolah Dasar 7(2), 204.

Paramandhita, Ade. Penerapan Ajaran Tri Hita Karana Pada Anak Usia Dini Di Tk Dharmayasa Kecamatan Klungkung Kabupaten Klungkung: Jurnal Penelitian Agama Hindu 1(2), (205-208).

Purbosari, Para Mitta. 2016. Pembelajaran Berbasis Proyek Membuat Ensiklopedia Ilmu Pengetahuan Alam ( IPA ) Untuk Meningkatkan Academic Skill Pada Mahasiswa: Scholaria ,231-38.

Purnomo. 2018. Keefektifan Model Pembelajaran Stad Dan Circ Ditinjau Dari Hasil Belajar Matematika Siswa Kelas 4 SD: Jurnal Unimus.5(1), 36-48.

Putra, Purniadi. 2017. "Pendekatan Etnopedagogi Dalam Pembelajaran IPA SD / MI: Primary Education Journal (PEJ) 1(1), 17-23.

Putra, Randi Eka, dan Ade Marta Putra. 2018. Meningkatkan Proses Belajar Siswa Pada Mata Pelajaran Pendidikan Jasmani Dengan Materi Passing Bawah Bola Voli Mini Melalui Pembelajaran Kooperatif Model Stad Pada Siswa Kelas V Sd Negeri 168 / li Sumber Mulya Kabupaten Bungo: Jurnal Muara Olahraga1(1), 87-97.

Rahayu, E. S., \& Made Nuryata. 2013. Pembelajaran Masa Kini. Jakarta: Sekarmita.

Sudana \& Astra Wesnawa. 2017. Penerapan Model Pembelajaran Kooperatif Tipe Stad Untuk Meningkatkan Hasil Belajar IPA: Jurnal Ilmiah Sekolah Dasar, 1(1): 1-6

Solihah. 2016. Pengaruh Model Pembelajaran Teams Games Tournament (TGT) Terhadap Hasil Belajar Matematika: Jurnal SAP 1(1). 45-53.

Suryaniti., dkk. 2017. "Pengaruh Model Pembelajaran Student Team Achievement Division Berbantuan Media Audio Visual Animasi Terhadap Kompetensi Pengetahuan IPA: eJournal PGSD Universitas Pendidikan Ganesha Mimbar PGSD 5(2), 1-10.

Tri Rahmawati, Senja. 2019. Penerapan Model Pembelajaran Kooperatif Tipe Stad Untuk Simbaringin Kutorejo Mojokerto Abstrak Penelitian Ini Didasarkan Atas Rendahnya Keterampilan Siswa Dalam Menulis Narasi , Yang Dibuktikan Dengan Masih Belum 
Lengkap Dan Runtutnya Hasil Tulisan Narasi, Jurnal Pendidikan Guru Sekolah Dasar, 7(7), 3751-3760.

Utami, Lia. 2017. Pengaruh Model Pembelajaran Student Teams Achievement Divisions Berbantuan Media Gambar Terhadap Penguasaan Kompetensi Pengetahuan Ipa Siswa Kelas V Sd Gugus Letkol Wisnu Denpasar Utara Tahun Pelajaran 2016/2017, e-Journal PGSD Universitas Pendidikan Ganesha Mimbar PGSD,5(2). 1-10

Utami, Putri dan Wahidul Basri. 2019. Pengaruh Model Stad Terhadap Hasil Belajar Siswa Pada Mata Pelajaran Sejarah Indonesia. Jurnal Penelitian Aktual dan Kajian Analisis Reformasi Pendidikan, 13-25.

Wibisana., Ni Nyoman Kusmariyatni \& Kadek Yudiana. 2019. "Pengaruh Model Cooperatif Script Berbasis Tri HitA, Jurnal Pendidikan Multikultural Indonesia 2(2), 66-75.

Zahro., dkk. 2018. Pengaruh model pembelajaran student team achievement devision (STAD) dan mind mapping terhadap hasil belajar siswa kelas IV sekolah dasar: Jurnal Pendidikan Dasar dan Pembelajaran, 8(2), 196-205. 